\title{
Hubungan Indeks Osilasi Selatan dan Indeks Curah Hujan terhadap Kejadian Kekeringan di Kabupaten Indramayu, Jawa Barat, Indonesia
}

\author{
The Relation of Southern Oscillation Index and Standard Precipitation Index to \\ Drought Disaster in Indramayu District, West Jawa, Indonesia
}

\author{
BOEDI TJAHJONO ${ }^{*}$, BABA BARUS ${ }^{1}$, NINA WIDIANA DAROJATI ${ }^{1}$ \\ ${ }^{1}$ Pusat Studi Bencana, Lembaga Penelitian dan Pengabdian kepada Masyarakat, Institut Pertanian Bogor, \\ Jl. Raya Pajajaran, Kampus IPB Baranangsiang, Bogor; "Penulis korespondensi, e-mail: \\ boetjah@apps.ipb.ac.id \\ (Diterima: 14 Oktober 2016; Disetujui: 27 Desember 2016)
}

\begin{abstract}
Indramayu district experiences frequent droughts that leads to many paddy fields harvest failure. Since the district is one of the national granary, this disaster needs to be addressed urgently. This study aimed to assess the level of dryness in Indramayu using Standard Precipitation Index (SPI) and its relation with the Southern Oscillation Index (SOI). The study used monthly rainfall data from 1996 to 2013 observed by 19 stations and the score of SOI that came from the Bureau of Meteorology of Australia. The method used quantitative approach using SPI and software SPI_sl_6.exe. Drought indices was measured in four different time scale which are 1, 3, and 6 month(s) (for the short term period) and the 12 months time scale (for the long term period). SPI's assessment was classified in accordance with the classification of WMO (World Meteorological Organization) which consist of seven classes, ranging from wet extreme to dry extreme class. The results showed that the occurence of "very dry" to "dry extreme " drought was occured mainly from February 1997 to January 1998 at most stations, while for some stations, it lasted until March 1998. The drought period was lasted from nine to ten months. In 2002 to 2003, the droughts that classified as "very dry" on a 3 and 6 months time scale lasted about five months, while the 12 months time scale was lasted about nine months. SPI value that obtained from different time scales has a strong relation with the value of SOI. The negative value of SOI tends to be followed by the negative value of SPI, and vice versa. SOI that has negative value below -7 and occured in a long period (more than three months) indicates a prolonged El Nino which occurred in 1997 and 2002/2003 when the research area was struck by "being dry" to "dry extreme" drought state.
\end{abstract}

Keywords: drought, Indramayu district, southern oscillation index, standard precipitation index.

\begin{abstract}
ABSTRAK
Kabupaten Indramayu sering mengalami kekeringan sehingga menyebabkan banyak lahan sawah yang puso. Mengingat kabupaten ini merupakan wilayah lumbung padi nasional, maka bencana ini perlu segera diatasi. Penelitian ini bertujuan menilai tingkat kekeringan di Kabupaten Indramayu melalui Indeks standar curah hujan (SPI) dan keterkaitannya dengan Indeks Osilasi selatan (SOI). Penelitian ini menggunakan data curah hujan bulanan dari tahun 1996 sampai 2013 dari 19 stasiun pencatat hujan dan data SOI dari Badan Meteorologi Australia. Metode yang digunakan adalah secara kuantitatif dengan menggunakan formula SPI dan piranti lunak
\end{abstract}


SPI_sl_6.exe. Indeks kekeringan dihitung untuk empat skala waktu, yaitu 1, 3, dan 6 bulanan (periode jangka pendek) dan 12 bulanan (periode jangka panjang). Hasil penilaian SPI diklasifikasikan sesuai dengan klasifikasi WMO (World Meteorologi Organization) yang terdiri atas tujuh kelas, mulai dari kelas ekstrim basah hingga ekstrim kering. Hasil penelitian menunjukkan bahwa kejadian kekeringan yang tergolong "sangat kering" hingga "ekstrim kering", terjadi rata-rata di tiap stasiun mulai Februari 1997 hingga Januari 1998, bahkan di beberapa lokasi dapat berlangsung hingga Maret 1998. Periode kekeringan terpantau berlangsung selama 9 hingga 10 bulan. Pada tahun 2002 sampai 2003, kejadian kekeringan "sangat kering" pada skala waktu 3 dan 6 bulanan berlangsung sekitar 5 bulan sedangkan pada skala 12 bulanan berlangsung sekitar 9 bulanan. Nilai SPI yang diperoleh dari berbagai skala waktu memiliki hubungan yang erat dengan nilai SOI. Pada saat nilai SOI negatif maka nilai SPI pun cenderung bernilai negatif, begitu pula sebaliknya. SOI yang bernilai negatif lebih kecil dari -7 dan berlangsung lama (lebih besar dari tiga bulan) menunjukkan terjadinya El Nino yang berkepanjangan, terjadi pada tahun 1997 dan 2002/2003 yang wilayah penelitian berada pada kondisi kekeringan "kering sedang" hingga "ekstrim kering".

Kata kunci: kekeringan, indeks curah hujan, indeks osilasi selatan, Kabupaten Indramayu

\section{PENDAHULUAN}

Kekeringan merupakan gejala klimatologis yang sering menimbulkan bencana, terutama untuk petani karena kekeringan sering menyebabkan gagal panen atau puso. Berdasarkan data Dinas Pertanian Kabupaten Indramayu, lahan yang mengalami puso di Kabupaten Indramayu mempunyai luasan yang tidak konstan setiap tahunnya. Tahun 2002 hingga 2009 rata-rata luas lahan puso mencakup 12,787 hektar [Tabel 1], sedangkan pada tahun 2012, lahan yang mengalami puso tercatat seluas 13,173 hektar (Dinas Pertanian, 2012). Dengan demikian kekeringan menjadi isu utama bidang pangan di Kabupaten Indramayu yang harus segera dicari solusinya.

Tabel 1. Kejadian puso di Kabupaten Indramayu

\begin{tabular}{cc}
\hline Tahun kejadian & Luas Lahan Puso (Ha) \\
\hline 2002 & 8,026 \\
2003 & 25,640 \\
2004 & 3,026 \\
2005 & 2,666 \\
2006 & 16,546 \\
2007 & 14,803 \\
2008 & 28,615 \\
2009 & 2,459 \\
\hline
\end{tabular}

Sumber: Dinas Pertanian, Indramayu (2002 sampai 2009).
Kekeringan pada dasarnya adalah keadaan kekurangan pasokan air untuk berbagai kegiatan di suatu wilayah dan terjadi dalam waktu yang berkepanjangan, dari bulanan hingga tahunan (UNDP, 2011). Secara meteorologi kekeringan dilihat sebagai kondisi kekurangan curah hujan untuk suatu jangka waktu tertentu pada suatu wilayah (Misrha dan Singh, 2010). Oleh karenanya, terdapat beberapa penelitian yang menganalisis kekeringan dengan menggunakan data curah hujan bulanan. Adapula yang menggunakan pendekatan lain yakni menggunakan analisis durasi dan intensitas kekeringan dalam hubungannya dengan kekurangan curah hujan kumulatif. Sebagaimana yang dilakukan oleh Darojati et al. (2015) dalam penelitiannya di Kabupaten Indramayu yang memperoleh susunan faktor-faktor bahaya kekeringan di Kabupaten Indramayu secara berurutan sesuai urutan kepentingannya yakni curah hujan, jenis penggunaan lahan, jarak ke sumber air, tekstur tanah, suhu permukaan tanah. Curah hujan merupakan urutan pertama yang berarti merupakan faktor paling penting dalam bahaya kekeringan. Dalam hal tersebut digunakan data curah hujan bulanan.

Salah satu pemanfaatan data curah hujan untuk analisis kekeringan dapat dilakukan melalui penilaian Indeks Standard Presipitasi 
(Standardized Precipitation Index atau SPI) yang hasilnya dapat digunakan untuk memantau pasokan air jangka pendek dan jangka panjang. SPI memiliki kredibilitas dan relevansi baik teknis maupun kebijakan sebagai indikator yang dapat disajikan sebagai alat serbaguna dalam mewaspadai, pemantauan dan analisis kekeringan (Karavitis et al., 2011).

Secara klimatologis, gejala kekeringan juga dapat ditinjau melalui pola iklim wilayah. Pengukuran tersebut dilakukan dengan menggunakan Indeks Osilasi Selatan (Southern Oscillation Index/SOI). SOI adalah index standar berdasarkan pengamatan perbedaan tekanan atmosfir permukaan laut antara Tahiti dan Darwin, Australia. SOI merupakan pengukuran fluktuasi skala besar tekanan udara antara Pasifik tropis bagian barat dan timur. Pengukuran SOI dilakukan per hari namun penghitungan SOI disajikan per bulan. Kegiatan tersebut telah dilakukan oleh Badan meteorologi Australia.

Sebagaimana diketahui bahwa letak wilayah Indonesia berada di antara dua benua yakni benua Asia dan benua Australia, dan terletak di antara dua samudera yakni samudera Pasifik dan samudera Indonesia. Hal ini menyebabkan iklim di wilayah Indonesia (musim hujan dan kemarau) sangat dipengaruhi oleh pergerakan angin dan uap air dari wilayahwilayah tersebut. Nababan et al. (2015) menyatakan bahwa secara umum variabilitas anomali paras laut rata-rata (Mean Sea Level Anomaly/MSLA) di perairan Indonesia mengikuti pola musiman, berkorelasi positif dengan index SOI. SOI paling dominan di perairan utara Papua dan semakin kecil ke arah perairan Indonesia bagian barat.

Tujuan dari penelitian ini adalah melakukan analisis tingkat kekeringan di Kabupaten Indramayu, Provinsi Jawa Barat, dengan metode indeks standar curah hujan (SPI) dan dikorelasikan dengan indeks osilasi selatan (SOI).

\section{METODOLOGI}

Kabupaten Indramayu terletak di wilayah pesisir utara Provinsi Jawa Barat atau terletak pada posisi $107^{\circ} 51^{\prime}-108^{\circ} 36^{\prime}$ Bujur Timur dan $6^{\circ} 15^{\prime}-6^{\circ} 40^{\prime}$ Lintang Selatan. Data yang digunakan berasal dari data sekunder, yaitu data curah hujan bulanan antara tahun 1996 hingga 2013 (17 tahun) yang dikumpulkan dari 19 stasiun pencatat hujan. Data yang lain adalah data SOI dari Badan Meteorologi Australia (BOM, 2016).

\section{Data curah hujan}

Pada data curah hujan yang diperoleh terdapat data yang kosong. Kekosongan disebabkan oleh kerusakan alat atau pun oleh penyebab lainnya. Oleh karena itu kekosongan data perlu diatasi agar data tersebut dapat dipakai. Untuk mengatasi hal tersebut maka data yang kosong diprediksi melalui metode aritmatik aljabar. Metode ini merupakan metode yang paling sederhana dan praktis untuk memprediksi data yang hilang sehingga menjadi lengkap dan kontinyu. Tahapan yang dilakukan adalah menjumlahkan data curah hujan dari stasiun di sekitarnya yang berdekatan dan membagi dengan jumlah stasiun yang digunakan tersebut (Saputro, 2011). Rumusan untuk menghitungnya adalah sebagai berikut:

$$
\mathrm{Rx}=1 / \mathrm{n}\left(\sum \mathrm{Ri}\right)
$$

Dimana:

$\mathrm{Rx}=$ data curah hujan yang hilang/kosong

$\mathrm{Ri}=$ curah hujan yang digunakan dari stasiunstasiun sekitarnya

$\mathrm{N}=$ banyaknya stasiun curah hujan terdekat yang digunakan

\section{Penentuan nilai indeks kekeringan}

Data curah hujan yang telah diperbaiki tersebut selanjutnya dapat digunakan untuk analisis kekeringan dengan metode indeks standar curah hujan (Standardized Precipitation Index atau SPI). SPI menjadi sebuah pengukuran kekeringan yang populer. Jahangir (2013) dan Mahtab (2013) menggunakan metode tersebut dalam risetnya. 
Adapun persamaan yang digunakan adalah sebagai berikut:

$$
\mathrm{Zij}=\frac{X \mathrm{ij}-\mathrm{Xi}}{\sigma_{\mathrm{j}}}
$$

Dimana:

$\mathrm{Xij}=$ Hujan rata-rata bulan ke $\mathrm{j}$ pada rentang tahun $\mathrm{i}$ $\mathrm{Xi}=$ Hujan rata-rata dalam rentang tahun $\mathrm{i}\left(\mathrm{t}_{1}-\mathrm{t}_{\mathrm{n}}\right)$

$\sigma_{\mathrm{j}}=$ Standar deviasi hujan dalam rentang tahun $\mathrm{i}$ $\left(t_{1}-t_{n}\right)$

$\mathrm{Zij}=$ Indeks standar curah hujan (Standardized precipitation Index/SPI)

Untuk analisis data curah hujan dalam penelitian ini digunakan piranti lunak (software) SPI_sl_6.exe. Indeks dihitung untuk skala waktu 1, 3, 6, dan 12 bulanan. Skala waktu 1, 3, dan 6 bulanan merupakan periode jangka pendek, sedangkan untuk skala waktu 12 bulanan merupakan periode jangka panjang. Dalam penelitian ini klasifikasi nilai SPI menggunakan klasifikasi dari WMO (2012), yakni dibedakan menjadi tujuh kelompok yang memperlihatkan indeks bahaya kekeringan [Tabel 2].

Tabel 2. Kelas Indeks Curah Hujan Standar (SPI)

\begin{tabular}{lllc}
\hline No & \multicolumn{1}{c}{ Nilai } & \multicolumn{1}{c}{ Kategori } & Kelas \\
\hline 1 & $\geq 2.00$ & Ekstrim Basah & 1 \\
2 & $1.5-1.99$ & Sangat Basah & 2 \\
3 & $1-1.4$ & Basah Sedang & 3 \\
4 & $-0.99-0.99$ & Normal & 4 \\
5 & $-1.49--1.00$ & Kering Sedang & 5 \\
6 & $-1.99--1.5$ & Sangat Kering & 6 \\
7 & $\leq-2.00$ & Ekstrim Kering & 7 \\
\hline
\end{tabular}

Sumber: WMO (2012).

\section{Penilaian nilai Indeks Osilasi Selatan (Southern Oscillation Index/SOI)}

Untuk nilai SOI dalam penelitian ini menggunakan data dari Badan Meteorologi Australia. Data ini didapatkan melalui pengukuran perbedaan tekanan muka air laut secara rutin di Pasifik bagian timur (TahitiPolinesia) dan pasifik bagian barat (DarwinAustralia). Nilai SOI dihitung menggunakan formula yang dirumuskan oleh Troup (1965), setelah direvisi oleh National Climate Centre
(NCC). Persamaan tersebut adalah sebagai berikut

(sumber: www.longpaddock.qld.gov.au):

$$
\mathrm{SOI}=\frac{10\left(\mathrm{P}_{\text {diff }}-\mathrm{P}_{\text {diffav }}\right)}{\mathrm{SD}\left(\mathrm{P}_{\text {diff }}\right)}
$$

Dimana:

$\mathrm{P}_{\mathrm{diff}}=$ selisih antara rata-rata bulanan tekanan muka air laut di Tahiti dengan rata-rata bulanan tekanan muka air laut di Darwin

$\mathrm{P}_{\text {diffav }}=$ rata-rata jangka panjang $\mathrm{P}_{\text {diff }}$ di bulan yang dimaksud

$\mathrm{SD}\left(\mathrm{P}_{\text {diff }}=\right.$ Standar deviasi jangka panjang dari $\mathrm{P}_{\text {diff }}$ di bulan yang dimaksud

SOI $=$ Indeks Osilasi Selatan

Nilai SOI negatif menunjukkan tekanan permukaan laut lebih besar atau suhu laut lebih dingin di Darwin daripada di Tahiti. Dan sebaliknya, nilai SOI positif menunjukkan tekanan permukaan laut lebih besar atau suhu air laut lebih dingin di Tahiti dibandingkan dengan di Darwin. Nilai SOI secara erus menerus kurang dari -7 menunjukkan episode El Nino, dan nilai SOI secara terus-menerus lebih dari +7 menunjukkan episode La Nina (www.bom.gov.au/climate/current/soi2.shtml, 2016).

Penelitian ini menggunakan data SOI yang sudah tersedia dari Badan meteorologi Australia yakni data SOI tahun 1996 sampai 2013 (BOM, 2016). Tinjauan terhadap SOI diperlukan untuk melihat keterkaitan kondisi iklim di wilayah Pasifik dengan lokasi penelitian yang berhadapan dengan perairan Laut Jawa.

\section{HASIL DAN PEMBAHASAN}

\section{Indeks Curah Hujan Standar (SPI)}

Pada data curah hujan yang dikumpulkan, terdapat beberapa stasiun yang datanya kosong dikarenakan stasiun tersebut mengalami kerusakan alat penakar hujan. Stasiun-stasiun tersebut adalah Jatibarang, Kedokanbunder dan Sudikampiran. Tabel 3 berikut menunjukkan beberapa kekosongan 
data yang dimaksud, kemudian dilakukan pengisian data dengan metode aritmatik aljabar. Hasil analisis SPI (periode 1996 - 2013) terlihat bahwa di setiap skala waktu menunjukkan adanya pergeseran nilai.

Tabel 3. Kekosongan data beberapa stasiun curah hujan dan nama stasiun terdekat

\begin{tabular}{|c|c|c|}
\hline Stasiun & $\begin{array}{c}\text { Data } \\
\text { yang hilang }\end{array}$ & $\begin{array}{c}\text { Stasiun } \\
\text { terdekat }\end{array}$ \\
\hline Jatibarang & $\begin{array}{l}2002-7 \text { s.d. } \\
2002-12 \\
2003-1 \text { s.d. } \\
2003-12 \\
2004-1 \text { s.d. } \\
2004-2\end{array}$ & $\begin{array}{l}\text { Bangkir, Kertasmaya, } \\
\text { Loh bener, } \\
\text { Sudimampir, } \\
\text { Sukadana, Ujunggaris }\end{array}$ \\
\hline Kedokanbunder & $\begin{array}{l}2000-1 \text { s.d. } \\
2002-2\end{array}$ & $\begin{array}{l}\text { Juntinyuat, } \\
\text { Krangkeng, } \\
\text { Kertasmaya, } \\
\text { Sudikampiran }\end{array}$ \\
\hline Sudikampiran & $\begin{array}{l}2002-5 \text { s.d. } \\
2002-12 \\
2003-1 \text { s.d. } \\
2003-12\end{array}$ & $\begin{array}{l}\text { Juntinyuat, } \\
\text { Kertasmaya, } \\
\text { Sudimampir, } \\
\text { Ujunggaris }\end{array}$ \\
\hline
\end{tabular}

Pada Tabel 4 nilai SPI ekstrim ditunjukkan pada setiap skala waktu serta lokasi stasiun yang mempunyai nilai ekstrim tersebut. Sebagai acuan, SPI yang bernilai di antara -1 sampai dengan 1 merupakan kondisi yang normal, sedangkan untuk nilai SPI lebih dari 1 menunjukkan akumulasi air sehingga dikategorikan pada kondisi basah, dan sebaliknya untuk nilai SPI yang kurang dari -1 menunjukkan kondisi defisit air atau kondisi kering. Jika kondisi basah atau kering tersebut terjadi berkelanjutan, maka kondisi tersebut menggambarkan terjadinya penggenangan (banjir) atau kekeringan (kemarau panjang).

Tabel 4. Kejadian ekstrim nilai SPI

\begin{tabular}{|c|c|c|c|c|c|}
\hline SPI ${ }_{1996-2013}$ & & Rataan & SPI & Stasiun & $\begin{array}{c}\text { Waktu } \\
\text { kejadian }\end{array}$ \\
\hline \multirow{2}{*}{1 bulanan } & Min & -2.1 & -2.8 & Kertasmaya & $2008-5$ \\
\hline & Max & 2.2 & 3.1 & Bangkir & 1996-3 \\
\hline \multirow[b]{2}{*}{3 bulanan } & Min & -1.7 & -3.5 & Loh bener & $2009-4$ \\
\hline & Max & 1.8 & 2.7 & $\begin{array}{c}\text { Indramayu; } \\
\text { Sukadana }\end{array}$ & $\begin{array}{l}2002-2 \\
2002-3 \\
2013-8\end{array}$ \\
\hline \multirow[b]{2}{*}{6 bulanan } & Min & -2.0 & -3.0 & Loh bener & $2009-7$ \\
\hline & Max & 1.8 & 2.9 & $\begin{array}{c}\text { Indramayu; } \\
\text { Kedokan } \\
\text { bunder }\end{array}$ & $\begin{array}{l}2002-4 \\
2010-9\end{array}$ \\
\hline \multirow[b]{2}{*}{12 bulanan } & Min & -1.8 & -3.0 & Loh bener & $2009-11$ \\
\hline & Max & 1.5 & 2.6 & Indramayu & $\begin{array}{c}2002-6 \text { s.d } \\
2002-10\end{array}$ \\
\hline
\end{tabular}

Pada Tabel 4 nilai SPI rata-rata di lokasi penelitian menunjukkan adanya rentang nilai yang ekstrim kering hingga sangat basah. Pada setiap skala waktu (1, 3, 6, 12 bulanan) kondisi di setiap stasiun dapat mengalami kondisi yang ekstrim kering dan ekstrim basah. Tabel 4 memperlihatkan pula bahwa wilayah di sekitar stasiun-stasiun tersebut merupakan wilayah yang mengalami kondisi ekstrim, baik pada skala waktu 1, 3, 6, atau 12 bulanan. Wilayah di sekitar stasiun curah hujan Indramayu, misalnya, merupakan wilayah yang cenderung mengalami kondisi ekstrim basah baik pada skala waktu 3, 6, maupun 12 bulanan. Sebaliknya stasiun Loh Bener mengalami kondisi ekstrim kering pada skala waktu yang sama. Dengan demikian wilayah-wilayah stasiun di atas dapat dijadikan sebagai titik acuan dalam memantau perubahan iklim baik untuk pemantauan kondisi basah maupun kekeringan.

Berdasarkan hasil analisis tersebut, pola pergerakan nilai SPI dari masing-masing stasiun pada setiap skala waktu dapat dilihat pada Gambar 1, sedangkan pola pergerakan rataan nilai SPI digambarkan pada Gambar 2. Pada skala waktu satu bulanan, fluktuasi pergerakan nilai SPI terhadap angka nol kerap terjadi sehingga grafik terlihat sangat rapat. Namun pada skala waktu 3 atau 6 bulanan perubahan pola grafik tampak lebih renggang di setiap periode bulan basah ataupun bulan kering dibandingkan dengan SPI pada skala waktu satu bulanan. Adapun pada skala waktu 12 bulanan perubahan nilai SPI menjadi tidak tajam lagi dan selang perubahan nilai positif dan negatif SPI menjadi lebih pendek. Mc. Kee et al. (1993) menyatakan kondisi tersebut menunjukkan kurang merespon terhadap perubahan curah hujan.

Gambar 1 dan Gambar 2, dapat pula membantu untuk mengetahui kapan puncak kekeringan berawal dan berakhir serta masa berlangsungnya kejadian kekeringan tersebut. Berdasarkan pola grafik di atas dapat diketahui bahwa pada tahun 1997 terjadi kekeringan pada tingkat sangat kering hingga ekstrim kering. 
Pola ini dapat dilihat pada semua skala waktu, sebagai contoh pergerakan nilai SPI lebih kecil dari -1 (periode kekeringan) di setiap stasiun pada skala waktu 3 bulanan mulai bergerak pada bulan Februari 1997 hingga Januari 1998. Di beberapa stasiun berlangsung hingga bulan Maret 1998. Dalam hal ini periode kekeringan berlangsung 2 hingga 9 bulan, demikian pula pada skala waktu 6 bulanan, periode kekeringan berlangsung 2 hingga 10 bulan atau rata-rata terjadi selama 6 bulan, dari bulan Juli 1997 hingga April 1998. Adapun untuk skala waktu 12 bulanan, periode kekeringan berlangsung 1 hingga 8 bulan atau rata-rata 4 bulan yang berlangsung dari bulan November 1997 hingga Juni 1998. Dari beberapa stasiun terlihat pula bahwa periode kekeringan dimulai lebih awal dan/atau berakhir lebih lama.

Selain itu kejadian kekeringan terjadi pula pada tahun 2002 sampai 2003. Pada skala 3, 6 bulanan periode kekeringan berlangsung sekitar 5 bulan, pada skala 12 bulanan berlangsung hingga mencapai 9 bulan, sedangkan pada beberapa lokasi, periode kekeringan dimulai lebih awal dan/atau berakhirnya lebih lama.
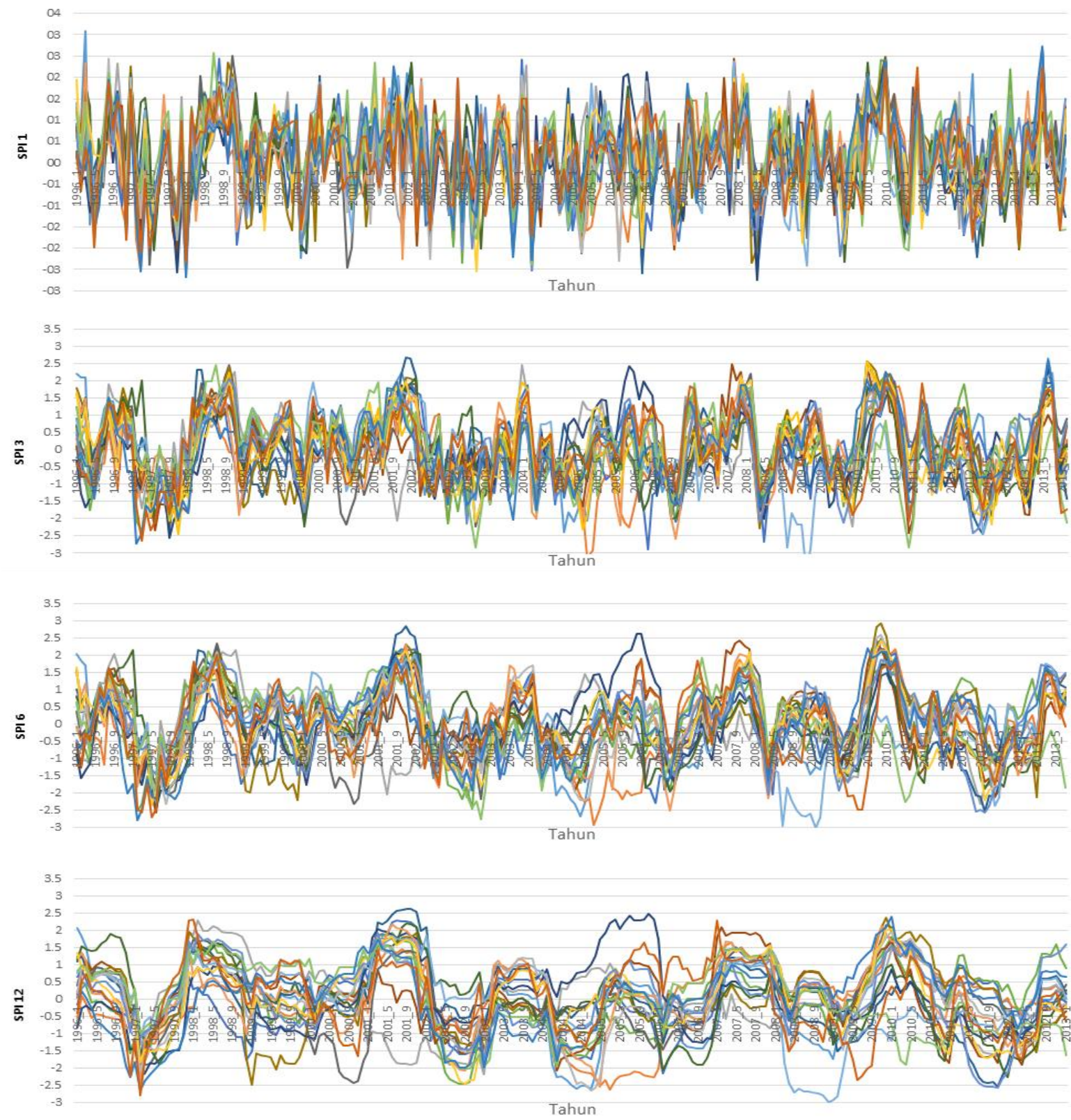

Gambar 1. Pola pergerakan nilai SPI di masing-masing stasiun curah hujan pada berbagai skala waktu *keterangan: setiap warna garis yang berbeda mewakili stasiun curah hujan yang berbeda. 


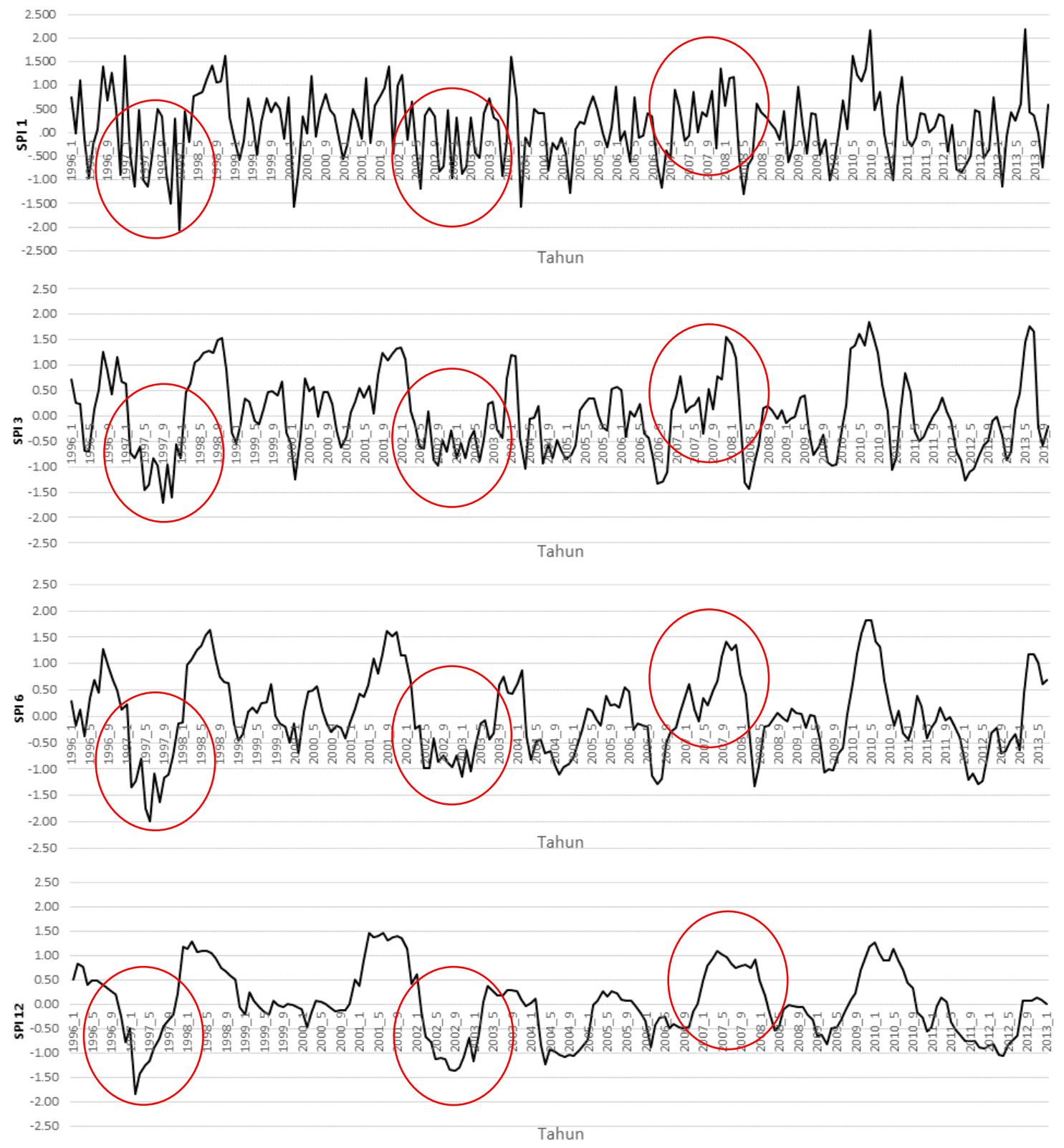

Gambar 2. Pola pergerakan rataan nilai SPI masing-masing stasiun curah hujan pada berbagai skala waktu *keterangan: tanda lingkaran merah pergeseran pola grafik pada tiap skala waktu

\section{Indeks Osilasi Selatan (SOI)}

Nilai SOI sebagaimana disajikan pada Tabel 5 dan Gambar 3, menunjukkan bahwa pada tahun 1997 telah terjadi perbedaan tekanan muka air laut di Tahiti dan Darwin pada posisi di bawah angka 0 dengan kisaran -8.5 hingga -24 . Kejadian ini terjadi berturutturut mulai bulan Maret 1997 hingga April 1998. Hal ini menunjukkan bahwa terjadinya El Nino sebagai penyebab terjadinya kemarau panjang di tanah air. Demikian halnya dengan kejadian kekeringan periode tahun 2002 sampai
2003 yang tergolong sangat kering, ketika nilai SOI mencapai -10.6 pada tahun 2002 dan mencapai -12 pada tahun 2003. Angka tersebut terlihat bahwa kejadian El Nino berdampak agak lebih ringan daripada kejadian pada tahun 1997. Namun demikian kejadian yang berat serupa tahun 1997 terjadi kembali pada tahun 2015 hingga awal tahun 2016, ketika nilai SOI mencapai -11.2 pada tahun 2015 dan mencapai -22 pada tahun 2016. 


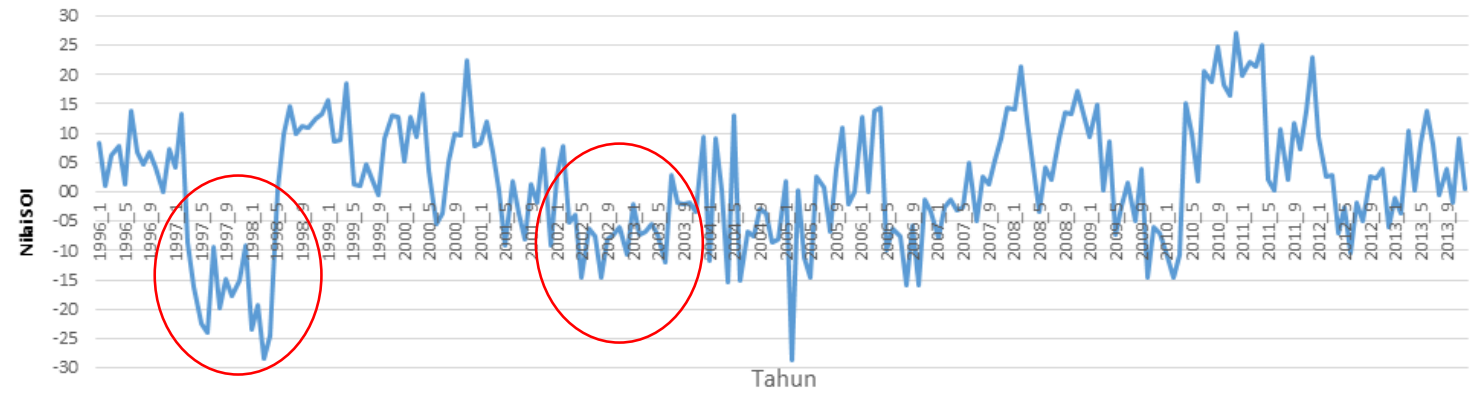

Gambar 3. Indeks Osilasi Selatan bulanan

Tabel 5. Data bulanan Indeks Osilasi Selatan (Southern Oscillation Index/SOI)

\begin{tabular}{|ccccccccccccc|}
\hline Year & Jan & Feb & Mar & Apr & May & Jun & Jul & Aug & Sep & Oct & Nov & Dec \\
\hline $\mathbf{2 0 1 6}$ & -19.7 & -19.7 & -4.7 & -22.0 & 2.8 & 5.8 & 4.2 & 5.3 & 13.5 & - & - & - \\
$\mathbf{2 0 1 5}$ & -7.8 & 0.6 & -11.2 & -3.8 & -13.7 & -12.0 & -14.7 & -19.8 & -17.8 & -20.2 & -5.3 & -9.1 \\
$\mathbf{2 0 1 4}$ & 12.2 & -1.3 & -13.3 & 8.6 & 4.4 & -1.5 & -3.0 & -11.4 & -7.6 & -8.0 & -10.0 & -5.5 \\
$\mathbf{2 0 1 3}$ & -1.1 & -3.6 & 10.5 & 0.3 & 8.4 & 13.9 & 8.1 & -0.5 & 3.9 & -1.9 & 9.2 & 0.6 \\
$\mathbf{2 0 1 2}$ & 9.4 & 2.5 & 2.9 & -7.1 & -2.7 & -10.4 & -1.7 & -5.0 & 2.6 & 2.4 & 3.9 & -6.0 \\
$\mathbf{2 0 1 1}$ & 19.9 & 22.3 & 21.4 & 25.1 & 2.1 & 0.2 & 10.7 & 2.1 & 11.7 & 7.3 & 13.8 & 23.0 \\
$\mathbf{2 0 1 0}$ & -10.1 & -14.5 & -10.6 & 15.2 & 10.0 & 1.8 & 20.5 & 18.8 & 24.9 & 18.3 & 16.4 & 27.1 \\
$\mathbf{2 0 0 9}$ & 9.4 & 14.8 & 0.2 & 8.6 & -7.4 & -2.3 & 1.6 & -5.0 & 3.9 & -14.7 & -6.0 & -7.0 \\
$\mathbf{2 0 0 8}$ & 14.1 & 21.3 & 12.2 & 4.5 & -3.5 & 4.2 & 2.2 & 9.1 & 13.5 & 13.4 & 17.1 & 13.3 \\
$\mathbf{2 0 0 7}$ & -7.8 & -2.7 & -1.4 & -3.0 & -2.7 & 5.0 & -5.0 & 2.7 & 1.4 & 5.4 & 9.2 & 14.4 \\
$\mathbf{2 0 0 6}$ & 12.7 & 0.1 & 13.8 & 14.4 & -9.8 & -6.3 & -7.6 & -15.9 & -5.8 & -16.0 & -1.4 & -3.5 \\
$\mathbf{2 0 0 5}$ & 1.8 & -28.6 & 0.2 & -11.2 & -14.5 & 2.6 & 0.9 & -6.9 & 3.9 & 10.9 & -2.0 & 0.1 \\
$\mathbf{2 0 0 4}$ & -11.6 & 9.1 & 0.2 & -15.4 & 13.1 & -15.2 & -6.9 & -7.6 & -2.8 & -3.7 & -8.6 & -8.0 \\
$\mathbf{2 0 0 3}$ & -2.0 & -7.4 & -6.8 & -5.5 & -7.4 & -12.0 & 2.9 & -1.8 & -2.2 & -1.9 & -3.4 & 9.3 \\
$\mathbf{2 0 0 2}$ & 2.7 & 7.7 & -5.2 & -3.8 & -14.5 & -6.3 & -7.6 & -14.6 & -8.2 & -7.4 & -6.0 & -10.6 \\
$\mathbf{2 0 0 1}$ & 8.4 & 11.9 & 6.7 & 0.3 & -9.0 & 1.8 & -3.7 & -8.2 & 1.4 & -1.9 & 7.2 & -9.1 \\
$\mathbf{2 0 0 0}$ & 5.1 & 12.9 & 9.4 & 16.8 & 3.6 & -5.5 & -3.7 & 5.3 & 9.9 & 9.7 & 22.4 & 7.7 \\
$\mathbf{1 9 9 9}$ & 15.6 & 8.6 & 8.9 & 18.5 & 1.3 & 1.0 & 4.8 & 2.1 & -0.4 & 9.1 & 13.1 & 12.8 \\
$\mathbf{1 9 9 8}$ & -23.5 & -19.2 & -28.5 & -24.4 & 0.5 & 9.9 & 14.6 & 9.8 & 11.1 & 10.9 & 12.5 & 13.3 \\
$\mathbf{1 9 9 7}$ & 4.1 & 13.3 & -8.5 & -16.2 & -22.4 & -24.1 & -9.5 & -19.8 & -14.8 & -17.8 & -15.2 & -9.1 \\
$\mathbf{1 9 9 6}$ & 8.4 & 1.1 & 6.2 & 7.8 & 1.3 & 13.9 & 6.8 & 4.6 & 6.9 & 4.2 & -0.1 & 7.2 \\
\hline
\end{tabular}

Keterangan: bagian yang di-highlight adalah yang mempunyai nilai negatif $\leq-7$ dan terjadi minimal tiga bulan berturut-turut (yaitu yang menunjukkan adanya gejala El Nino)

Sumber: Badan Meteologi Australia, 2016. www.bom.gov.au

Sayang sekali pada penelitian ini hasil nilai SOI tidak dapat disandingkan dengan nilai SPI dikarenakan keterbatasan data curah hujan yang ada. Kejadian kekeringan periode tahun 2006 sampai 2007 yang tergolong kering sedang pada skala waktu 3 maupun 6 bulanan berlangsung selama rata-rata 3 bulan, yakni dari September 2006 hingga Januari 2007. Akan tetapi pada skala 12 bulanan kondisi tersebut tidak terlihat dan berada pada kondisi normal. Nilai SOI pada tahun tersebut menunjukkan perubahan yang hampir sama dengan periode tahun 2002 sampai 2003.

Gambaran grafik SPI baik pada skala waktu 1, 3, 6, maupun 12 bulanan jika dibandingkan dengan grafik SOI di atas, menunjukkan adanya keterkaitan. Dengan demikian dapat disimpulkan bahwa kejadian kekeringan di Kabupaten Indramayu dipengaruhi oleh adanya kejadian El Nino. 
Data kerugian puso pada tahun 2002, 2003, 2006, dan 2007 dapat disebabkan oleh terjadinya El Nino di perairan Pasifik. Adapun kerugian puso pada tahun 2008 bukan diakibatkan oleh kejadian kekeringan El Nino dikarenakan nilai SPI pada periode tahun 2007 sampai 2008 menunjukkan kondisi yang basah. Kondisi ini diperkuat oleh nilai SOI yang juga bernilai positif.

\section{KESIMPULAN DAN REKOMENDASI}

Indeks standar curah hujan atau SPI dan Indeks Osilasi Selatan atau SOI, keduanya dapat digunakan untuk memantau kejadian kekeringan pada suatu wilayah. Nilai SPI pada berbagai skala waktu $(1,3,6$, dan 12 bulanan) dan SOI memiliki hubungan yang erat, ketika pada saat nilai SOI negatif, maka nilai SPI pun cenderung bernilai negatif. Begitu pula sebaliknya, pada saat nilai SOI positif maka nilai SPI pun berada pada nilai positif.

Nilai SOI negatif lebih kecil dari -7 yang berlangsung lama (lebih besar dari 3 bulan) menunjukkan terjadinya El Nino yang panjang. Kondisi ini mempengaruhi wilayah penelitian sehingga berada pada kondisi kering, yaitu kelas kering sedang hingga ekstrim kering. Kondisi ini terjadi pada SPI dan SOI pada tahun 1997.

Diketahuinya pola kekeringan melalui analisis SPI dan SOI, maka direkomendasikan kepada Dinas Pertanian untuk menyarankan kepada petani agar dapat mengatur pola tanam sesuai dengan pola kekeringan alami (El Nino).

\section{Ucapan Terima Kasih}

Penelitian ini dibiayai oleh Direktorat Riset dan pengabdian Masyarakat Direktorat Jenderal Penguatan Riset dan Pengembangan Kementerian Riset, Teknologi dan Pendidikan Tinggi sesuai dengan Surat Perjanjian Penugasan Pelaksanaan Program Penelitian Nomor: 079/SP2H/LT/DRPM/Il/2016 tanggal 17 Februari 2015. Untuk itu, kami ucapkan terima kasih kepada seluruh instansi terkait atas pembiayaan kegiatan penelitian kami ini sehingga penelitian ini dapat berjalan dengan lancar.

\section{DAFTAR PUSTAKA}

Alam, A. T. M. J., Rahman, M. S., \& Saadat, A. H. M. (2013). Monitoring Meteorological and Agricultural Drought Dynamics in Barind Region Bangladesh Using Standard Precipitation Index and Markov Chain Model. International journal of Geomatics and Geosciences, 1 (3).

Bureau of Meteorology, Australian Goverment. (2016). Southern Oscillation Index (SOI) History. Diakses dari: www.bom.gov.au/ climate/current/soi2.shtml

Darojati, N. W., Barus, B \& Sunarti, E. (2015). Pemantauan Bahaya Kekeringan di Kabupaten Indramayu. Jurnal Tanah dan Lingkungan, 17, (2). ISSN 1410-7333.

Dinas Pertanian dan Peternakan Kabupaten Indramayu. (2002-2012). Laporan Tahunan.

Karavitis, C. A., Alexandris, S., Tsesmelis, D. E., \& Athanasopoulos, G. (2011). Application of the Standardized Precipitation Index (SPI) in Greece. Water, 3, 787-805. doi:10.3390/ w3030787.

Mc Kee, T. B., Doeskan, N. J., \& Kleist, J. (1993). The Relationship of Drought Frequency and Duration to Time Scales. Eighth Conferences on Applied Climatology, 17-22 January 1993. Anahem, California.

Mishra, A.K., \& Singh, V. P. (2010). A Review of Drought Concepts. Journal of Hydrology. 391, 202-216.

Nababan, B., Hadianti, S., \& Natih, N. M. N. (2015). Dinamika Anomali Paras Laut Perairan Indonesia. Jurnal Ilmu dan Teknologi Kaelautan Tropis, 7 (1), 259-272.

Queensland Government. (2016). SOI Data Files. Diakses dari: www.longpaddock.qld.gov.au/ seasonalclimateoutlook/southernoscillationin dex/soidatafiles.

Saputro, D. R. S., Mattjik A. A., Boer, R., Wigena, A. H., \& Djuraidah, A. (2011). Pendugaan Data Tidak Lengkap Curah Hujan di Kabupaten Indramayu dengan Kriging dan Rata-Rata Bergerak (Moving Average) (Berdasarkan Data Tahun 1980-2000). Prosiding Seminar Nasional Statistika Universitas Diponegoro 2011, 171-182. ISSN ISBN:978-979-097-142-4. 
Shad, M. S., Marvili, M. D., \& Farsani, P. A. (2013). Zoning Drought by Standardized Precipitation Index in Esfahan Province (IRAN). International Journal of Advanced Biological and Biomedical Research, 1 (1), 477-481. ISSN: $2322-4827$.

Troup, A. J. (1965). The Southern Oscillation. Quarterly Journal of Royal Meteorological Society. 91, 490-506

United Nations Development Programme. (2011). Mainstreaming Drought Risk Management, A primer. United Nations.

World Meteorology Organization. (2012). Standardized Precipitation Index, User Guide. WMO-No. 1090, Geneva. 